\title{
IV. OPERATIONS RESUME, DSDP, LEG 36
}

\author{
Otis M. Moore, Amoco Production Company, Lafayette, Louisiana
}

\section{INTRODUCTION}

Leg 36 of the Deep Sea Drilling Project started on 30 March 1974 at Ushuaia, Argentina, and ended 52.61 days later at Rio de Janeiro, Brazil, on 22 May 1974. The Challenger traveled $4653.4 \mathrm{n}$. mi. and drilled a total of 10 holes at six sites in the Drake Passage, Falkland Plateau, Falkland (Malvinas) Outer Basin, and Argentine Basin. Water depths varied between 1531.5 meters $\left(5025^{\prime}\right)$ and 5103 meters $\left(16,743^{\prime}\right)$. Maximum penetration reached below the ocean floor was 575.5 meters $\left(1888^{\prime}\right)$ while the longest drill string worked during the leg was 5574 meters $\left(18,288^{\prime}\right)$.

Time distribution for the 52.61 days total leg time was 24.93 days cruising, 20.65 days on site, 4.52 days port time, and 2.51 days other time (Figure 1). Total site time of 20.65 days was divided into 6.09 days coring, 1.79 days drilling, 5.52 days trips, 5.55 days wait on weather, 1.04 days lost to dynamic positioning problems, 0.66 days other time (includes mechanical downtime, routine maintenance, etc.). (See Figure 2.)

A total of 2480 meters of ocean sediments was penetrated, of which $40.6 \%$ was cored. A total of 107 cores was attempted during the leg with $95.3 \%$ of the cores attempted having usable recovery. Average recovery on all cores cut during the leg was $57.5 \%$. This recovery percentage, on all cores cut, is in line with the Project average to date of approximately $55 \%$.

Scientifically, most of the success stories derived from Leg 36 will be the result of the drilling program conducted in the Falkland Plateau area and the two relatively successful holes drilled and cored in the Falkland (Malvinas) Outer Basin area. Very little scientific information is likely to be derived from the other holes spudded due to their lack of penetration. Outside of the two mentioned areas, the deepest penetration reached on any of the other holes was 53 meters with core recovery on only the first core taken at the ocean floor.

The elements, in general, played havoc with operations during Leg 36. The Challenger was in three hurricane-force storms plus being subjected to hundreds of icebergs while on site as well as while underway. Due to the influence of the elements, five of the 10 holes spudded during Leg 36 had to be abandoned before achieving the scientific objectives. All scientific objectives were reached on only two of the holes. It might be noted that none of the holes was abandoned due to poor or unstable hole conditions. An interesting statistic, that will not appear as such in the text of this report, is the total time lost either directly or indirectly to the elements during Leg 36 . A very close estimate of this lost time will amount to a total of 13.88 days or $26.4 \%$ of the total leg time. The human element of decision making on site, etc., is involved in some of this lost

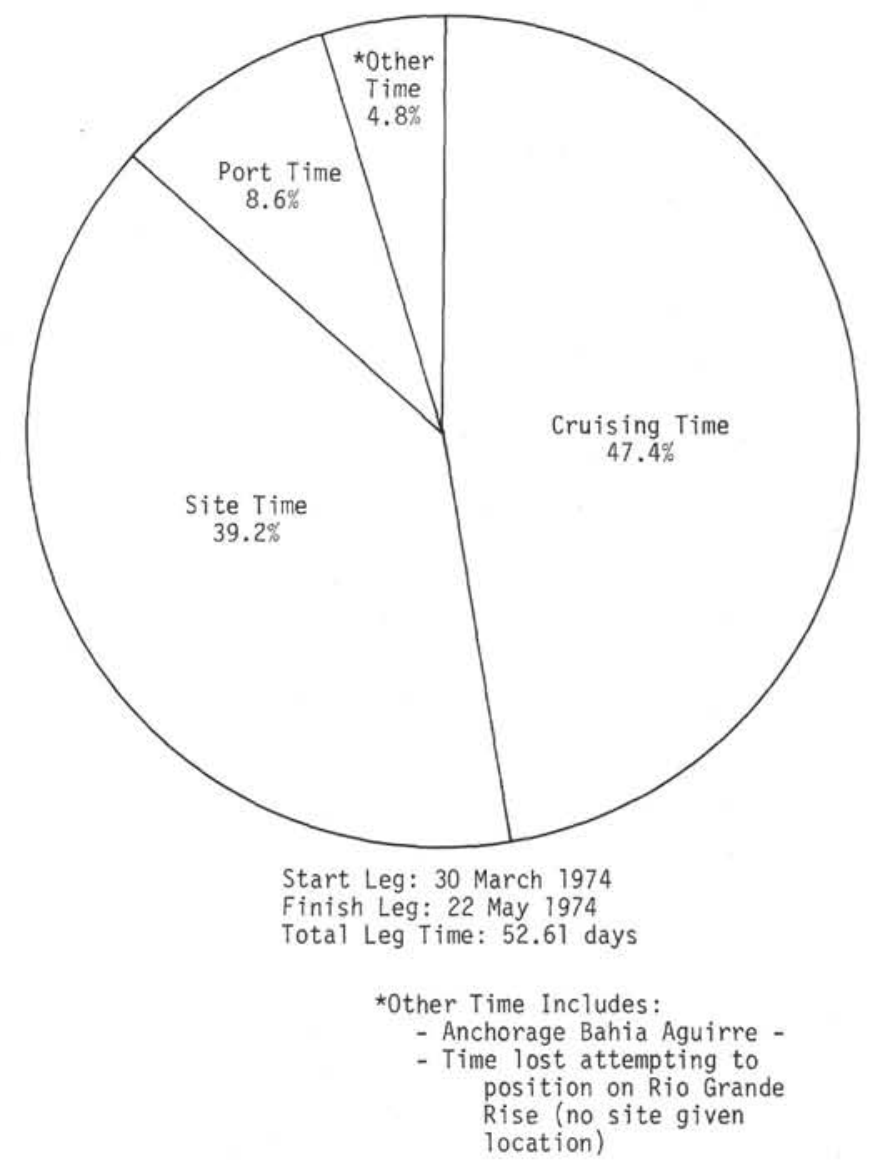

Figure 1. Deep Sea Drilling Project total time distribution, Leg 36.

time and therefore, one might rightfully contest the validity of this statistic.

The elements, indeed, dealt harshly with drilling operations throughout the leg, but the thing that was to finally turn the lights out on Leg 36 was the Challenger's dynamic positioning system. While positioning over the final drill site on the Rio Grande Rise, the power supply to the vertical reference gyro failed and all efforts to restore the power to the gyro were unsuccessful, thus ending operations for Leg 36.

\section{VOYAGE SUMMARY}

The first site on Leg 36 was in the Drake Passage area at latitude $56^{\circ} 35^{\prime} \mathrm{S}$ and longitude $65^{\circ} 18.2^{\prime} \mathrm{W}$. Soon after departing the sheltered waters of the Beagle Channel, approximately $8 \mathrm{hr}$ out of Ushuaia, Argentina, the sea conditions began to build. By midnight of 4 April 1974, the Challenger was experiencing rolls of $20^{\circ}-25^{\circ}$ with pitches of $5^{\circ}-8^{\circ}$ on a due south course. As we approached Site 326, weather conditions were 


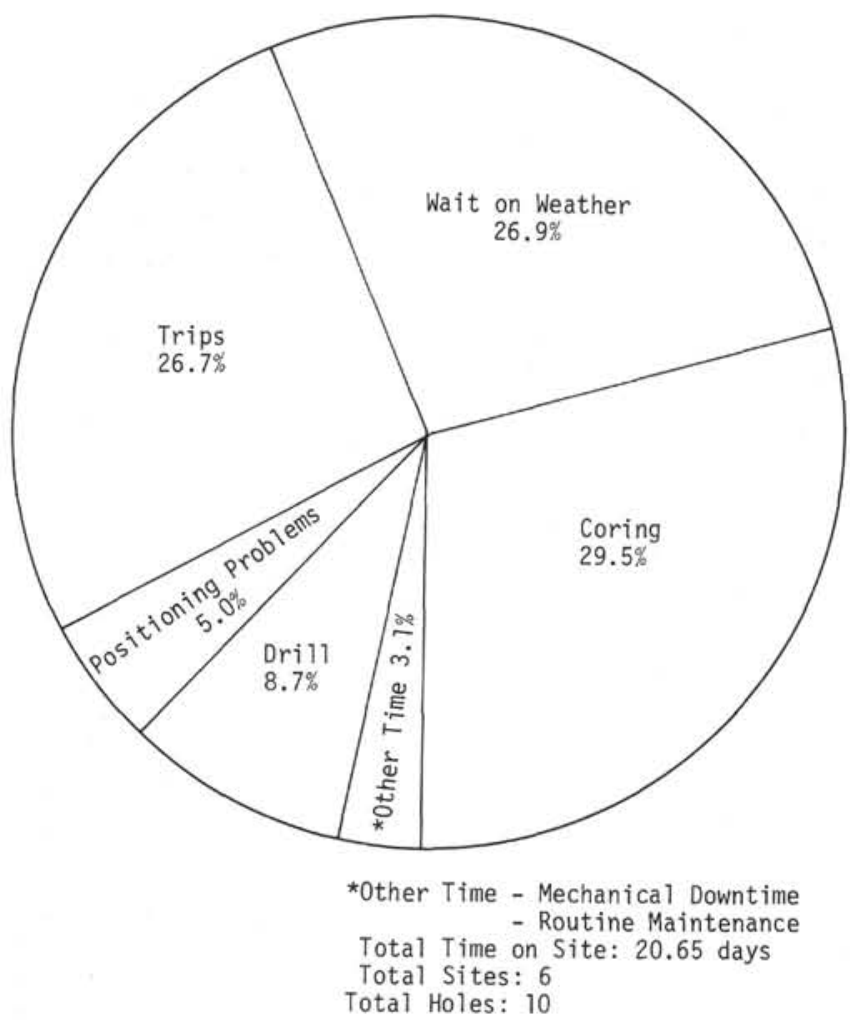

Figure 2. Deep Sea Drilling Project site time distribution, Leg 36.

deemed too bad to drop a site beacon, so the ship continued on by the proposed site at reduced speed to do additional survey work while the weather conditions improved. By $1500 \mathrm{hr}, 5$ April 1974, the sea conditions had improved; winds northwest $30 \mathrm{mph}$, seas northwest 4-6ft, swells northwest $14-16 \mathrm{ft}$. The beacon was dropped while weather conditions continued to improve. By 2200 hours 5 April 1974, the weather had improved, winds north northwest $20 \mathrm{mph}$, swells northwest $10 \mathrm{ft}$, roll $3^{\circ}$, pitch $3^{\circ}$. The worst, however, was yet to come for Site 326. As the bit neared the ocean floor, the winds and seas were on the increase again. The hole was spudded to obtain the first punch cores, but it then became necessary to pull the bit above the ocean floor to await better positioning of the vessel. While positioning back over the beacon, the drill string parted resulting in the loss of the complete drill string plus the bottom-hole assembly. (For comments concerning this failure, refer to Addendum 1.)

Having secured the rig floor equipment, the Challenger departed Site 326 on the night of 6 April 1974 enroute to sheltered waters to pick up a new drill string and bottom-hole assembly. As the nearest sheltered area was the Beagle Channel, radio contact was made with the Argentine Navy to gain permission to anchor. The Argentines directed the Challenger to Bahia Aguirre area which required no pilotage. The drill ship went on anchor at $1700 \mathrm{hr}, 7$ April 1974 and started making up a replacement drill string. Just after midnight an officer of the Argentine Coast Guard boarded the Challenger to investigate the circumstances causing the drill ship to seek anchorage again in Argentine waters. The officer departed the Challenger and later, by radio, informed us that the drill ship was to remain at anchor until given clearance to leave the area by the Argentine Coast Guard. The Challenger was detained for a total of $35 \mathrm{hr}$ by the Argentine Officials, but since the crews were continuing to pick up drill pipe, the actual lost time due to the detainment was $15 \frac{1}{2} \mathrm{hr}$. The Challenger was released to get underway at $2130 \mathrm{hr}, 9$ April 1974.

Site 327 , our second site, was planned at latitude $50^{\circ} 52.3^{\prime} \mathrm{S}$, longitude $45^{\circ} 47^{\prime} \mathrm{W}$, in the Falkland Plateau area. The time lost as a result of the drill string failure, that is additional cruising time, time at anchorage in Bahia Aguirre, and Argentine detainment, will be included in time assigned to Site 327. Weather again played an active part in operations during site time on Site 327 . Hole 327 was abandoned due to bad weather after obtaining only the initial punch core at the ocean floor. Hole 327A met with much more success. After reaching a significant penetration of 469.5 meters, it too had to be abandoned due to the bad weather. Excessive rolling of the ship (rolls greater than $9^{\circ}$ ) caused the abandonment.

Having been rolled out of Hole $327 \mathrm{~A}$, so to speak, by $9^{\circ}$ rolls, the drill ship departed Site 327 at $1800 \mathrm{hr}, 17$ April 1974 on a course of $130^{\circ}$ heading southeasterly with good intentions of drilling the Proposed Site 36-4 in the central Scotia Sea (north) at latitude $56^{\circ} 20^{\prime} \mathrm{S}$, longitude $39^{\circ} 47^{\prime} \mathrm{W}$. Again, the elements had a few surprises in store for us. On the morning of 19 April 1974 at $0845 \mathrm{hr}$, our first iceberg was sighted at latitude $55^{\circ} 37.3^{\prime} \mathrm{S}$, longitude $41^{\prime} 21.9^{\prime} \mathrm{W}$. Since noon of 18 April, the barometric pressure had been steadily falling. The lowest recorded pressure was noted to be 28.12 in. mercury at $1535 \mathrm{hr}, 19$ April 1974. The profile gear was pulled in and all equipment secured for the expected storm. At $1600 \mathrm{hr}$, winds were recorded gusting to 70 $\mathrm{mph}$ as the seas and swells increased. By $2200 \mathrm{hr}$, the winds were gusting to $80 \mathrm{mph}$ from the southwest. The ship's course at the time was $165^{\circ}$ and speed 150 turns while experiencing rolls to $25^{\circ}$ and pitches to $11^{\circ}$. By 060020 April, the ship was unable to hold heading into the wind and seas with the aid of the thrusters at full power. At this time the winds were southwest $60 \mathrm{mph}$, swells southwest $25-30 \mathrm{ft}$, rolls $10^{\circ} 20^{\circ}$, pitches $5^{\circ}-10^{\circ}$. At $0615 \mathrm{hr}$, the ship was forced to reverse course and run with the elements to the northeast. At $1400 \mathrm{hr} 20$ April, while on a course of $060^{\circ}$ and experiencing 50 mph winds and swells of $25-35 \mathrm{ft}$, the ship's captain was forced to continue northeasterly to better weather and abandon all efforts to drill Proposed Site 36-4. At 1220 hr 21 April, numerous icebergs were sighted while running on the $060^{\circ}$ course, position latitude $54^{\circ} 49.6^{\prime} \mathrm{S}$, longitude $33^{\circ} 15^{\prime} \mathrm{W}$. Winds were down to $30-40 \mathrm{mph}$ and swells running 20 feet. At $1700 \mathrm{hr} 21$ April, a decision was made mutually by the ship's Captain, Cruise Operations Manager, and the Co-Chief Scientists to abandon all efforts to drill the Proposed 36-6 location (outer wall of South Sandwich Trench). Many icebergs could be seen now in the area of the ship. As darkness approached, the ship's speed was reduced for travel 
through the night in this hazardous environment. Hundreds of icebergs continued to be sited along our course to Proposed Site 36-9C, which would now be drill Site 328. The Challenger arrived at Site 328, Malvinas Outer Basin, at $0400 \mathrm{hr}$ on 24 April 1974 and still in iceberg country. Site location was latitude $49^{\circ} 48.7^{\prime} \mathrm{S}$, longitude $36^{\circ} 39.5^{\prime} \mathrm{W}$. Approximately $4 \frac{1}{2}$ days cruising time had been lost. Three holes were spudded on Site 328, two of the three being affected by the elements before reaching all scientific objectives. Increasing winds and swells caused the abandonment of Hole 328. An iceberg passing within four-tenths of a mile of our site location caused loss of Hole 328B. Thoughts of drilling Hole $328 \mathrm{C}$ were envisioned, but the extended forecast of inclement weather for the area soon cancelled this. It must be noted here that the human element was involved to some degree in the ultimate loss of Hole 328B and the resultant damage to the drill string. (For added detail regarding the loss of Hole $328 \mathrm{~B}$, refer to Addendum II.)

As the Challenger departed Site 328 at $1715 \mathrm{hr} 30$ April 1974, on a course $261^{\circ}$ back to the Falkland Plateau area and Site 329, the icebergs, once again, were out in force and were to play havoc with our planned course of travel. At $2043 \mathrm{hr}$, it became necessary to make our first course deviation to av.oid icebergs in the area. The ship's course was changed to $295^{\circ}$ and speed reduced due to hazardous conditions. Not long after the last iceberg for Leg 36 had been sighted at latitude $49^{\circ} 02^{\prime} \mathrm{S}$, longitude $39^{\circ} 10^{\prime} \mathrm{W}$, the bad weather that had been forecast for the area arrived to confront the Challenger with hurricane-force winds and maximum swells estimated at $40-50 \mathrm{ft}$ on the morning of 2 May 1974. The ship's speed had to be reduced at times to 150 turns due to heavy vibration caused by the cavitation of the propellers. Site 329, latitude $50^{\circ} 39.31^{\prime} \mathrm{S}$, longitude $46^{\circ} 5.73^{\prime} \mathrm{W}$, was reached at 2220 hr, 3 May 1974, with good weather conditions prevailing.

The cruise between Sites 328 and 329 had required an additional $31 \mathrm{hr}$ to negotiate. Again, the lost time was attributable to the elements.

The crews. aboard the Challenger basked in good weather during the drilling of Sites 329 and 330. Site 330 was nearby at latitude $50^{\circ} 55.2^{\prime} \mathrm{S}$, longitude $46^{\circ} 53^{\prime} \mathrm{W}$. Weather did deteriorate somewhat as Hole $330 \mathrm{~A}$ was abandoned and the Challenger got underway for the Argentine Basin site.

After an unusually uneventful cruise, the Challenger arrived at Site 331 , latitude $37^{\circ} 53^{\prime} \mathrm{S}$, longitude $38^{\circ} 7^{\prime} \mathrm{W}$, on 12 May 1974, only to face yet another storm with winds of hurricane force. The weather forecast issued for space period 13-14 May indicated good weather, wind light and variable. The ship's weatherman issued a revised forecast during the morning of 13 May indicating stronger winds and swells, wind northerly 20$30 \mathrm{mph}$, swells northerly 4-7 ft. Based on the apparently good weather forecasted, the crews started running pipe and the hole was spudded at noon, 13 May 1974. By $1830 \mathrm{hr}$, however, the drill pipe was started out of the hole due to increasing winds and seas. The pipe was pulled very slowly with the assurance that by morning it could be returned to bottom with the weather improved. By the morning of 14 May, however, weather conditions continued to deteriorate to the point of being too hazardous to finish pulling drill pipe out of the hole. The storm raged as 2187 meters of drill string was left hanging below the drill ship, suspended from the elevators. Winds were recorded at $90 \mathrm{mph}$ maximum, swells increased to $30-40 \mathrm{ft}$. The drill ship had been blown off site by some 5-6 miles by the time the storm had subsided. As marginal weather conditions continued to prevail and due to the remaining leg time growing ever so short, the decision was made to abandon Site 331 and trek north during the marginal weather anticipating using the remaining leg time to drill a site proposed on the Rio Grande Rise.

The Challenger got underway at $1745 \mathrm{hr}, 16 \mathrm{May}$ 1974 , on a northerly course. Seas were down to a smooth cruising condition by the following day, and the crews enjoyed the uneventful trip north as the temperatures warmed somewhat. Having dropped the beacon at $0200 \mathrm{hr}, 20$ May 1974, there was just one disappointment left for the crews aboard the Challenger on the Rio Grande Rise. While positioning over the beacon and having just gone into automatic mode of positioning, the power supply to the vertical reference gyro in the computer room failed. All efforts to restore the power to the gyro were unsuccessful and the ship could not be positioned on site. Drilling and coring operations were abruptly concluded for Leg 36 .

All that remained for Leg 36 was for Glomar Challenger to negotiate some $400 \mathrm{mi}$ of the South Atlantic Ocean into Rio de Janeiro; she did so in grand style arriving at $0915 \mathrm{hr}$ on 22 May 1974.

\section{DRILLING AND CORING - SITE SUMMARIES}

The accepted standard bottom-hole assembly was used during all coring and drilling operations on Leg 36. The assembly consisted of the following: Smith 10$1 / 8^{\prime \prime}$ bit Type F-94CK (4-cutter journal bearing insert type), float sub, $8-1 / 4^{\prime \prime}$ core barrel, three $8-1 / 4^{\prime \prime}$ drill collars, two Baash-Ross bumper subs, three $8-1 / 4^{\prime \prime}$ drill collars, two Baash-Ross bumper subs, two 8-1/4" drill collars, one 7-1/4" drill collar, and a range-3 joint of 5 $1 / 2^{\prime \prime}$ drill pipe. One of the lowermost bumper subs was inadvertently bent during coring operations at Site 327 and was removed from the assembly. The remaining sites were drilled with three bumper subs quite satisfactorily. The bottom-hole assembly has an effective weight of $30,000 \mathrm{lb}$ in seawater. The drill string used is $5^{\prime \prime}$ O.D. with 5-1/2" F.H. connections. The inner core barrel is a nonrotating $3-1 / 2^{\prime \prime}$ O.D. by $9-1 / 2$ meters barrel containing an inner plastic liner in which the 2 $3 / 8^{\prime \prime}$ O.D. core is captured during coring operations. All components of the drilling assembly has a minimum I.D. of 4" through which the inner barrel is retrieved.

At all sites during the leg the double soft formation finger-type catchers were used in the inner core barrel initially with the plastic sock run with the top catcher. This arrangement, as past records indicate, performed quite well with recovery in the softer formations normally high. There were three unexplained exceptions to this rule; the initial core on Hole 326 , and the second 
core taken on Holes 328A and 331. Four other occurrences of zero recovery were explained by the fact that the core barrel was bridged with basement rock above the Baker float, not letting the inner barrel reach its seat. As the sediments became firmer, the plastic sock was removed from service and the double soft formation catchers were run until such time harder sediments warranted going to one (upper) soft formation catcher and one (lower) finger-type hard formation catcher.

Once again, as past leg records indicate, the program of continuous coring offered the better percentage of recovery. At Hole 328, continuous coring through soft to firm clays offered an excellent $94 \%$ recovery. At Site 329 , the continuous coring program through the first 179.5 meters of penetration offered an excellent $93 \%$ recovery, while intermittent coring in the deeper and firmer sediments offered a disappointing $36 \%$ recovery.

\section{Site 326-Drake Passage}

As the drill string approached bottom on this site, weather conditions were beginning to deteriorate. The hole was spudded in a water depth of 3822 meters and a punch core of 9.5 meters was taken in soft sediments. Only 0.5 meter of usuable core was recovered. With the bit positioned above the ocean floor, while improving our position over the beacon, the drill string parted near the bottom of the drill ship losing a total of 389 joints of $5^{\prime \prime}$ drill pipe and a complete bottom-hole assembly. The site was abandoned at this point. The age of the sandy silt recovered is Quaternary.

\section{Site 327-Falkland Plateau}

Two holes were spudded at Site 327 . The original hole was abandoned due to weather and poor ship positioning after taking only a punch core in a water depth of 2411 meters by DPM. After a period of waiting on weather, Hole $327 \mathrm{~A}$ was spudded.

\section{Hole 327A}

Hole $327 \mathrm{~A}$ was continuously cored to a penetration of 118 meters, then intermittently cored to a total penetration of 469.5 meters. The hole was considered a scientific success even though all objectives were not reached before weather conditions deteriorated and maximum operating limits of roll forced abandonment of the hole. Hole 327A reached Aptian or Neocomian age claystone sediments.

\section{Site 328-Malvinas Outer Basin}

Three holes were spudded at Site 328 in a water depth of 5103 meters. Holes 328 and 328B reached significant depths before both were abandoned due to the elements. Hole 328A was abandoned after experiencing poor recovery on the second core. As the Co-Chief Scientist wanted better recovery over the upper interval, Hole $328 \mathrm{~B}$ was spudded. Hole 328 was intermittently cored to a depth of 5500 meters with a total penetration of 397 meters. The hole was bottomed in gray zeolitic claystone of Late Cretaceous age. The hole was ultimately abandoned when the elements increased to a point beyond the positioning capabilities of the ship. The position over the beacon was still being maintained adequately, but it was requiring nearly all available power to position the ship.

\section{Hole 328B}

Hole 328B was spudded in order to get better recovery in the interval missed by poor core recovery in Hole $328 \mathrm{~A}$ and to penetrate sediments not reached in Hole 328 . This hole was washed in to 5110 meters and then cored continuously to 5167.5 meters. The center bit was then dropped and pumped to its seat in the core barrel and then the hole was drilled to 5538 meters through the interval previously penetrated by Hole 328 . One additional core was cut from 5538-5547.5 meters, however while drilling at 5574 meters, operations were suspended due to an iceberg heading toward the Challenger. The bit was pulled to within a safe distance of the mudline (147 m below the ocean floor) to wait out the movement of the iceberg. The hole was subsequently lost and abandoned at the depth of 5574 meters with a maximum penetration of 471 meters. The sediments reached were brown zeolitic clays of Late Cretaceous age.

\section{Site 329-Falkland Plateau}

This site was selected to penetrate younger sediments in the Falkland Plateau area that had been missing in the previously drilled Hole 327A. The site was spudded in a water depth of 1531.5 meters and routinely cored and drilled to the objective subbottom depth of 464.5 meters. Upon reaching limestone sediments of late Paleocene age that overlapped sediments occurring in $327 \mathrm{~A}$, the site was abandoned.

\section{Site 330-Falkland Plateau}

The site was selected to complete the story on the Falkland Plateau, that is, to penetrate sediments older than those reached in Hole 327A and to date basement. The water depth at Site 330 was 2636 meters by PDR. Since the top sediments had been penetrated in Hole $327 \mathrm{~A}$, the bottom-hole assembly was quickly "drilled in" to a penetration of 129 meters, then the hole was cored and drilled intermittently to basement. A total penetration of 575.5 meters was reached with 19 meters of basement being cored. Basement in this case was granite. The oldest sediments were sandstone, siltstone, and lignite of middle-late Jurassic age. All scientific objectives were reached at Site 330 .

\section{Hole 330A}

With some time remaining for the site, the scientists wanted to take another look at the 129 meters of top sediments drilled in Hole 330 . The first core attempt recovered only 4.0 meters of usable core with a piece or basement rock noted to be in this recovery. The second core attempt failed to recover any usable core. A bridge in either the core barrel or bit was suspected. The center bit was dropped in an effort to clear the core barrel without success. Three additional attempts to core were made to a total penetration of 53 meters with no usable recovery. The hole was abandoned and the bit pulled. The bridge of basement rock was found above the Baker float valve. The bridge consisted of three pieces of core, the largest being $6^{\prime \prime}$ long. 


\section{Site 331-Argentine Basin}

This site was spudded in a water depth of 5073.5 meters of DPM. The first core taken has a $100 \%$ recovery of 8.5 meters of gray ooze. The second core failed to recover any usable core. The heave compensator had been picked up at this site and after the second core, was placed in operation. The heave compensator made approximately 8-12 strokes with a hook load of nearly $400,000 \mathrm{lb}$ when the main piston shaft seal started leaking hydraulic fluid badly. The compensator was set back at this point as winds and seas increased. No scientific information of any consequence was gained from the site. The age of the sediment recovered was Quaternary. The Challenger subsequently experienced a severe storm of hurricane force and was blown off the site beacon by approximately 5-6 mi. A second beacon was dropped but continued bad weather forced a decision to be made to move north in hope of better weather. Due to a subsequent failure of the ship's dynamic positioning system, Site 331 was the last site spudded for Leg 36 .

\section{SHIP'S DYNAMIC POSITIONING SYSTEM}

Performance of the dynamic positioning system during Leg 36 was inconsistent. On some sites the elements simply overran the capabilities of the system, but on others, the system failed to perform satisfactorily in generally good weather. The elements certainly had a detrimental effect on operations during the leg, but the thing that was to abruptly terminate operations on Leg 36 was the ship's dynamic positioning system. While positioning over the beacon on the final site for Leg 36 on the Rio Grande Rise, the power supply unit furnishing power to the vertical reference gyro failed, and subsequent efforts to make repairs failed and operations on Leg 36 were terminated. All that was left was the cruise into Rio de Janeiro. Hopefully, all of the positioning problems can be corrected during port call in Rio. Listed below are comments on the dynamic positioning concerning positioning performance at each site:

\section{Site 326}

Positioning was somewhat poor on the site due to marginal weather conditions. A strong current estimated at 3-4 knots apparently was affecting positioning quite a bit, in fact, apparently much more than was first realized. The scope on the bridge positioning equipment was found to also be a factor in positioning. The ship's position would not repeat when switching from one scale to another. This problem was corrected by changing out the scope. The drill string parted approximately $1 \mathrm{hr}$ after the scope was changed out while attempting to reposition over the beacon.

\section{Site 327}

Initially, the computer seemed to be slow in building up a memory to the existing environmental conditions at the time the ship was positioned over the beacon. In most instances, the computer would overreact to a signal, that is, it would overthrust the position. Part of the positioning problem was due to intermittent loss of acoustics caused by the unfavorable sea conditions and heavy roll and current sweeping thruster wash under the hydrophones. The hydrophones had been lowered to their lowermost position upon arrival, and improvements were not possible. In addition, the ship experienced an erratic behavior of the main shaft. This problem was resolved finally by changing a DX-15 card in the D-A converter for starboard shaft and reducing maximum thrust gain setting to $85 \%$. The acoustics problem improved as sea conditions improved by switching from hydrophones 1,2 , and 3 to hydrophones 1, 3, and 4 (No. 2 seemed more susceptible to noise). After these problems were resolved with the improved sea conditions, positioning was excellent in Automatic Mode for the remainder of site time, approximately $3^{1 / 2}$ days. It seems, however, that the ship's positioning capabilities can be overcome quite readily by adverse sea conditions particularly where there seems to be an appreciable current present.

\section{Site 328}

Upon dropping the beacon on site at $0400 \mathrm{hr}, 24$ April 1974, the ship came back to the beacon and positioned over same and went into Automatic Mode of positioning at $0500 \mathrm{hr}$. After $6 \mathrm{hr}$ (at $1100 \mathrm{hr}$ ), the ship started experiencing positioning problems due to erratic behavior of the mainshafts at high rpm's. The computer would call for slow rpm's ahead and the shafts would go full ahead at 200 rpm's. These excessively high rpm's would cause the ship to overshoot the beacon. The shafts were then called on to go astern hard. Thirty hours of trouble shooting were required to overcome these problems. During this time, some rig time was lost, however, the hole was spudded while positioning in Semi-Automatic Mode. During the trouble shooting, the $\mathrm{K} 4$ and $\mathrm{K} 5$ relays in the propulsion console were changed. Reference and feedback control voltages to the generators were set in the engine room and y-gains and maximum thrust were adjusted at the computer. The positioning was returned to Automatic Mode at $1700 \mathrm{hr}, 25$ April 1974. At $0830 \mathrm{hr}, 26$ April 1974, weather conditions required more power to the main shafts to maintain station, requiring 160 rpm's on both shafts. The excessive power demand by the positioning left insufficient power for drilling safely at a depth of 5500 meters. Drilling operations were suspended due to inadequate power to the rig floor. The ship was still being positioned in Automatic Mode, and the ship continued to position in Automatic until $2100 \mathrm{hr}$ on 29 April 1974. At this time, acoustics became intermittent due to disintegration of the beacon signal and adverse weather conditions. The ship was, at this time, returned to Manual Mode and a second beacon was dropped at $0055 \mathrm{hr}, 30$ April. The computer program was reloaded to wipe out the computer's memory and freshly restore anew all of the computer's instructions. Indications were that the main shafts were being overdriven. Positioning was somewhat improved, but wash from the thrusters still caused intermittent acoustic losses during high winds and seas when thrusting neared the limits of thrusters. Position was maintained in Automatic Mode until departing the site. 
There seems to be yet another problem, that of the beacon's image on the bridges positioning scope moving around the scope erratically at times. This movement occurs for no apparent reason indicating ship's movement at a speed that is just not possible. Apparently the image does return to its correct position, for in all cases, no ill effects were noted in our drilling operation, such as excess torque, drag, etc.

\section{Site 329}

The ship's dynamic positioning system functioned better at Site 329 than on any other site thus far on Leg 36 . Weather conditions were generally excellent during site time. The ship was placed in Automatic Mode of operation on arrival over the beacon and remained in Automatic Mode throughout site time. A few movements of the beacon image with relation to the scope screen occurred at times up to 120 feet excursions but this was, again, believed to be erratic movement and not necessarily true movement of the ship.

\section{Site 330}

The ship's dynamic positioning system functioned well at Site 330 . Weather conditions were generally good, however, the weather was rapidly deteriorating as Site 330 was completed. The barometer had been steadily falling.

\section{Site 331}

The ship's positioning system continued to perform erratically. Initially, at Site 331, the ship would not position in Automatic Mode. The thrusters, as well as the main shafts, would overreact to a signal. That is, the computer would call for too many rpm's and run past the position calling for main shafts to go astern at 200 rpm's. The beacon signal continued to move too abruptly at times on the positioning scope, taking apparent excursions of $120 \mathrm{ft}$ or more. The ship was finally placed in Automatic Mode successfully by going to Manual Mode and bringing the ship over the beacon and then going to Automatic Mode rather than going to Semi-Automatic and then to Automatic Mode as is the normal sequence of operations.

At Site 331, the elements completely overcame the positioning capabilities of the ship as the ship was blown off location some 5 or $6 \mathrm{mi}$ during the severe storm experienced while on site. Winds of $90 \mathrm{mph}$ with swells estimated at $50 \mathrm{ft}$ were recorded in the bridge's log during the storm.

\section{Proposed Site 36-11A}

The final site for Leg 36 was to be Site 332 on the Rio Grande Rise. The drill ship arrived at the site and dropped the beacon at $0200 \mathrm{hr}, 20$ April 1974. While positioning over the beacon at approximately $0315 \mathrm{hr}$, the gyro indicator light on the bridge's positioning panel went to red, indicating the loss of the gyro. Upon investigating, the gyro's power supply unit was found to be out of order. Efforts to correct the problem were unsuccessful, thereby bringing an abrupt halt to operations so far as Leg 36 was concerned. The proposed site was not given a site number. The rig time involved will be shown in leg statistics as other time.

\section{LOST TIME-THE ELEMENTS}

The elements were involved in cruising time and/or site time on all sites investigated during Leg 36 with only one exception, that being Site 330 . A total of $133.25 \mathrm{hr}$ of on-site time were Tost to the elements. In several instances, trips caused directly by the elements were also recorded in Leg 36 statistics as weather time. On more than one occasion, cruising times were lengthened significantly by the elements. Lost time, while underway, was not broken out as weather time but will be included in the cruising times even though a good estimate of lost time cruising is mentioned within this report.

Sites that were directly affected by the elements are listed as follows:

\section{Site 326}

Lost $4-1 / 2 \mathrm{hr}$ after spudding due to high winds and seas. The drill string parted just below the drill ship resulting in the loss of 389 joints of drill pipe plus a complete bottom-hole assembly.

\section{Hole 327}

Lost $8-1 / 2 \mathrm{hr}$. Had to pull bit due to reaching operational limits of $7^{\circ}$ roll.

\section{Hole 327A}

Lost $33-1 / 2 \mathrm{hr}$ before spudding due to excessive rolling of ship.

\section{Hole 328}

Lost $14-1 / 2 \mathrm{hr}$ due to increasing winds and swells requiring more power to adequately position ship. Elements forced trip. Assigned trip time to wait on weather.

\section{Hole 328B}

Lost 18-1/4 hr. Iceberg in area of ship forced trip as safety precaution and subsequent loss of hole.

Note: Due to elements, forced to abandon the drilling of proposed Sites 36-4 and 36-6. The Challenger required 4-1/2 days longer in finally arriving at Site 328. This additional cruising time will not be shown as wait on weather.

\section{Site 329}

No time lost on site due to weather.

Note: Estimated cruising time lost between Sites 328 and 329 due to icebergs and rough seas is $1 / 3$. days which will appear in statistics as cruising time to Site 329 .

Site 331

Lost $54 \mathrm{hr}$ after taking punch core. Storm hit preventing any additional drilling on site.

Tables 1 to 3 are summary sheets of the ship's positioning illustrating the average conditions faced by the Challenger while positioning on each site.

\section{COMMUNICATIONS}

During Leg 36, communications certainly were not outstanding, but it is believed that all parties concerned were kept adequately informed of the Challenger's daily progress and/or setbacks. The Challenger was in daily contact with Station WWD, San Diego, and could receive its traffic normally without problems, but occasionally WWD could not receive our traffic. Thus, some of the ship's traffic had to be sent via commercial means through VPC (Falkland Islands Radio) and later as the Challenger moved northward via PPR (Rio de Janeiro Radio). A diligent effort was made, however, to handle as much traffic as possible with WWD. 
TABLE 1

Summary of Operations, DSDP Leg 36

Total days on leg ( 30 March - 22 May 1974)

52.61

4.52

24.93

Total days cruising

20.65

Total days on site

2.51

Total days other time (time at anchorage Bahia Aguirre) (time attempting position Rio Grande Rise)

$\begin{array}{ll}\text { Coring time } & 6.09 \\ \text { Drilling time } & 1.79 \\ \text { Trip time } & 5.52 \\ \text { Waiting on weather } & 5.55 \\ \text { Dynamic positioning problems } & 1.04 \\ \text { Mechanical downtime and other (on site) } & 0.66\end{array}$

Total distance traveled $(\mathrm{n} \mathrm{mi})$

Average speed ( $\mathrm{n} \mathrm{mi})$

Sites investigated

Holes drilled

Number of cores attempted

Number of cores with recovery

Percent of cores with recovery

Total meters drilled

Total meters cored

Total meters recovered

Percent of core recovered

Total meters penetration

Maximum penetration at single holes $(\mathrm{m})$

Maximum water depth (m)
6.09

1.79

1.04
0.66
4653.4

7.78

6

10

107

102

95.3

1474.0

1006.0

578.7

57.5

2480

575.5

5103
Several radiotelephone calls to GMI's and DSDP's offices were made via commercial telephone high seas stations, WOM in Miami and KMI in Oakland. Several personal calls were also made through these stations.

On 23 April, the ship's TMC (main high power transmitter) went out and could not be repaired. As a result of this failure, the RCA CW transmitter was placed into service. Of course, this transmitter has less power than the TMC. During Leg 36, communications with the Navy were nonexistent.

Amateur radio (HAM) communications were somewhat spotty during Leg 36 , but most everybody expressing a desire to call the States got through at least once.

\section{PERSONNEL}

Global Marine's personnel performed well and are to be commended for their untiring efforts during some very difficult working conditions experienced during Leg 36.

The scientific party and SIO technician staff were all a fine group of people to be associated with; all expressed an enthusiasm in their work. The scientific party took the many operational problems experienced in stride and exhibited an understanding attitude.

\section{ADDENDUM I}

\section{DRILL STRING FAILURE-SITE 326 \\ 6 APRIL 1974-DRAKE PASSAGE}

As the Challenger approached the proposed drill Site 326, the weather conditions appeared marginal for dropping the positioning beacon. Upon mutual agreement between the Drilling Superintendent, Ship's Captain, and Operations Manager, it was agreed that no beacon would be dropped, instead the ship would steam on by the site while continuing to tow the profile gear. The vessel steamed approximately $18-1 / 2 \mathrm{mi}$ past the site location, made its turn and again, as the drill ship approached the site, it was decided that the weather had improved sufficiently to permit dropping the positioning beacon. The beacon was dropped on site with the understanding that the drill string would not be run until it was determined that the ship could be positioned over the beacon satisfactorily. By the time the bit was run near the bottom of the ocean, ship positioning began to deteriorate. Again, it was agreed that the initial core could be safely obtained. This initial core would be a punch core taken without circulating or rotating the drill string. Having successfully taken the punch core, the ship's positioning continued to be poor. Due to poor positioning, it was agreed that the bit would be pulled above the ocean floor and coring operations suspended until the ship was satisfactorily positioned over the site beacon.

At approximately $1800 \mathrm{hr}, 6 \mathrm{April} 1974$, the scope on the bridge positioning equipment was determined not to be operating properly. The ship's position would not repeat when switching from one scale to another. The scope was changed and the drill ship was being positioned back over the beacon while the drill string was hanging above the ocean floor. It was estimated, at this time, that the drill ship was approximately $3000 \mathrm{ft}$ off the beacon. At $1850 \mathrm{hr}$, the drill string parted near the bottom of the drill ship. The heave compensator was not being used at this time. The weather conditions at the time the drill string failed were recorded as: winds NW $50 \mathrm{mph}$, sea NW 6-8 ft, swell NW $17 \mathrm{ft}$ average, roll $8^{\circ}-10^{\circ}$, pitch $8^{\circ}-19^{\circ}$. The current at the time was unknown, but apparently the ship was experiencing the

TABLE 2

Site Summary DSDP Leg 36

\begin{tabular}{|c|c|c|c|c|c|c|c|c|c|c|c|c|c|c|}
\hline Hole & Latitude & Longitude & $\begin{array}{c}\text { Water } \\
\text { Depth } \\
(\mathrm{m})\end{array}$ & $\begin{array}{c}\text { Number } \\
\text { of } \\
\text { Cores }\end{array}$ & $\begin{array}{c}\text { Cores } \\
\text { with } \\
\text { Recovery }\end{array}$ & $\begin{array}{l}\text { Percent } \\
\text { with } \\
\text { Recovery }\end{array}$ & $\begin{array}{c}\text { Cored } \\
(\mathrm{m})\end{array}$ & $\begin{array}{l}\text { Recovered } \\
\text { (m) }\end{array}$ & $\begin{array}{l}\text { Recovered } \\
(\%)\end{array}$ & $\begin{array}{c}\text { Drilled } \\
\text { (m) }\end{array}$ & $\begin{array}{c}\text { Total } \\
\text { Penet. } \\
(\mathrm{m})\end{array}$ & $\begin{array}{l}\text { Avg. } \\
\text { Rate } \\
\text { Penet. }\end{array}$ & $\begin{array}{c}\text { Time } \\
\text { on } \\
\text { Hole } \\
\end{array}$ & $\begin{array}{l}\text { Time } \\
\text { on } \\
\text { Site } \\
\end{array}$ \\
\hline \multicolumn{15}{|c|}{ Drake Passage } \\
\hline 326 & $56^{\circ} 35^{\prime} \mathrm{S}$ & $65^{\circ} 18.2^{\prime} \mathrm{W}$ & 3822 & 1 & 1 & 100 & 9.5 & 0.5 & 5.3 & 0 & 9.5 & & 30.25 & 30.25 \\
\hline \multicolumn{15}{|c|}{ Falkland Plateau } \\
\hline $\begin{array}{l}327 \\
327 \mathrm{~A}\end{array}$ & $\begin{array}{l}50^{\circ} 52.3^{\prime} \mathrm{S} \\
50^{\circ} 52.3^{\prime} \mathrm{S}\end{array}$ & $\begin{array}{l}46^{\circ} 47.02^{\prime} W \\
46^{\circ} 47.02^{\prime} W\end{array}$ & $\begin{array}{l}2411 \\
2411\end{array}$ & $\begin{array}{r}1 \\
27\end{array}$ & $\begin{array}{r}1 \\
27\end{array}$ & $\begin{array}{l}100 \\
100\end{array}$ & $\begin{array}{r}5.0 \\
256.5\end{array}$ & $\begin{array}{r}5.0 \\
128.1\end{array}$ & $\begin{array}{r}100.0 \\
50.0\end{array}$ & $\begin{array}{c}0 \\
213.0\end{array}$ & $\begin{array}{r}5.0 \\
469.5\end{array}$ & 33.6 & $\begin{array}{l}24.50 \\
82.50\end{array}$ & 107.00 \\
\hline \multicolumn{15}{|c|}{ Falkland (Malvinas) Outer Basin } \\
\hline $\begin{array}{l}328 \\
328 \mathrm{~A} \\
328 \mathrm{~B}\end{array}$ & $\begin{array}{l}49^{\circ} 48.7^{\prime} \mathrm{S} \\
49^{\circ} 48.7^{\prime} \mathrm{S} \\
49^{\circ} 48.7^{\prime} \mathrm{S}\end{array}$ & $\begin{array}{l}36^{\circ} 39.5^{\prime} \mathrm{W} \\
36^{\circ} 39.5^{\prime} \mathrm{W} \\
36^{\circ} 39.5^{\prime} \mathrm{W}\end{array}$ & $\begin{array}{l}5103 \\
5103 \\
5103\end{array}$ & $\begin{array}{r}12 \\
2 \\
7\end{array}$ & $\begin{array}{r}12 \\
2 \\
7\end{array}$ & $\begin{array}{l}100 \\
100 \\
100\end{array}$ & $\begin{array}{l}112.0 \\
17 \\
66.5\end{array}$ & $\begin{array}{r}62.1 \\
7.4 \\
62.6\end{array}$ & $\begin{array}{l}55.4 \\
43.5 \\
94.0\end{array}$ & $\begin{array}{c}285.0 \\
0 \\
404.5\end{array}$ & $\begin{array}{r}397.0 \\
17.0 \\
471.0\end{array}$ & $\begin{array}{r}59.0 \\
100.0 \\
38.3\end{array}$ & $\begin{array}{l}68.00 \\
24.00 \\
65.25\end{array}$ & 157.25 \\
\hline \multicolumn{15}{|c|}{ Falkland Plateau } \\
\hline $\begin{array}{l}329 \\
330 \\
330 \mathrm{~A}\end{array}$ & $\begin{array}{l}50^{\circ} 39.3^{\prime} \mathrm{S} \\
50^{\circ} 55.2^{\prime} \mathrm{S} \\
50^{\circ} 55.2^{\prime} \mathrm{S}\end{array}$ & $\begin{array}{l}46^{\circ} 05.7^{\prime} \mathrm{W} \\
46^{\circ} 53.0^{\prime} \mathrm{W} \\
46^{\circ} 53.0^{\prime} \mathrm{W}\end{array}$ & $\begin{array}{l}1531.5 \\
2636 \\
2636\end{array}$ & $\begin{array}{r}33 \\
17 \\
5\end{array}$ & $\begin{array}{r}33 \\
17 \\
1\end{array}$ & $\begin{array}{r}100 \\
100 \\
20\end{array}$ & $\begin{array}{r}312.5 \\
161.5 \\
47.5\end{array}$ & $\begin{array}{r}215.0 \\
85.5 \\
4.0\end{array}$ & $\begin{array}{r}68.8 \\
53.0 \\
8.4\end{array}$ & $\begin{array}{r}152.0 \\
414.0 \\
5.5\end{array}$ & $\begin{array}{r}464.5 \\
575.5 \\
53.0\end{array}$ & $\begin{array}{l}46.8 \\
26.4 \\
57.6\end{array}$ & $\begin{array}{l}46.50 \\
49.50 \\
13.75\end{array}$ & $\begin{array}{l}46.5 \\
63.25\end{array}$ \\
\hline \multicolumn{15}{|c|}{ Argentine Basin } \\
\hline 331 & $37^{\circ} 53.0^{\prime} \mathrm{S}$ & $38^{\circ} 6.92^{\prime} \mathrm{W}$ & 5073.5 & 2 & 1 & 50 & 18.0 & 8.5 & 47.2 & 0 & 18.0 & 108.0 & 91.25 & 91.25 \\
\hline Total & & & & 107 & 102 & 95.3 & 1006.0 & 578.7 & 57.5 & 1474.0 & 2480.0 & & 495.5 & 495.5 \\
\hline
\end{tabular}


TABLE 3

Time Distribution, DSDP Leg 36

\begin{tabular}{|c|c|c|c|c|c|c|c|c|c|c|c|c|c|}
\hline Date & $\begin{array}{c}\text { Site } \\
\text { Number }\end{array}$ & Cruise & Trips & Drill & Core & $\begin{array}{l}\text { Stuck } \\
\text { Pipe }\end{array}$ & $\begin{array}{l}\text { Wait on } \\
\text { Weather }\end{array}$ & $\begin{array}{l}\text { Position } \\
\text { Ship }\end{array}$ & $\begin{array}{l}\text { Mechanical } \\
\text { Downtime }\end{array}$ & $\begin{array}{l}\text { In Port } \\
\text { Time }\end{array}$ & Other & $\begin{array}{l}\text { Total } \\
\text { Time }\end{array}$ & Remarks \\
\hline $30 \mathrm{Mar}-4$ April & Ushuaia & & & & & & & & & 108.50 & & 108.50 & Depart 08004 April 1974 \\
\hline 4-6 April & 326 & 31.25 & 16.00 & & 7.25 & & 4.50 & 7.50 & & & & 61.50 & Lost drill string \\
\hline 6-14 April & 327 & 101.50 & 11.00 & & 1.50 & & 8.50 & 2.00 & 1.50 & & 53.00 & 179.00 & Pick up new drill string \\
\hline 14-17 April & $327 \mathrm{~A}$ & & 6.75 & 7.25 & 34.50 & & 33.50 & & 0.50 & & & 82.50 & $\begin{array}{l}\text { Bent bumper sub. } \\
\text { Abandoned due to weather }\end{array}$ \\
\hline 17-26 April & 328 & 154.00 & 13.00 & 7.25 & 23,00 & & 14.50 & 10.25 & & & & 222.00 & Abandoned due to weather \\
\hline 26-27 April & $328 \mathrm{~A}$ & & 14.25 & & 3.25 & & & & 3.00 & & 3.50 & 24.00 & $\begin{array}{l}\text { Ran Schlumberger unit } \\
\text { Poor core recovery }\end{array}$ \\
\hline 27.30 April & $328 \mathrm{~B}$ & & 19.50 & 11.75 & 12.50 & & 18.25 & & 3.25 & & & 65.25 & Lost hole due to icebergs \\
\hline 30 April - 5 May & 329 & 77.00 & 11.25 & 3.25 & 32.00 & & & & & & & 123.50 & Reached objectives \\
\hline 5-8 May & 330 & 6.00 & 9.00 & 13.00 & 27.00 & & & & 0.50 & & & 55.50 & Reached objectives \\
\hline 8 May & $330 \mathrm{~A}$ & & 6.75 & 0.50 & 6.50 & & & & & & & 13.75 & Bridged core barrel \\
\hline 8-16 May & 331 & 100.50 & 25.00 & & 3.75 & & 54.00 & 5.25 & 0.75 & & 2.50 & 191.75 & Abandoned due to weather \\
\hline 16 May & To Rio & 128.00 & & & & & & & & & 7.50 & 135.50 & $\begin{array}{l}\text { Computer failed on } 20 \text { May } \\
1974 \text {; headed for Rio }\end{array}$ \\
\hline Total & & 598.25 & 132.50 & 43.00 & 146.25 & & 133.25 & 25.00 & 9.50 & 108.50 & 66.50 & 1262.75 & \\
\hline
\end{tabular}

Note: $26.9 \%$ On-Site Time $=$ WOW $; 5 \%$ On-Site Time $=$ Lost Position Problems; Site Time 495.5 hrs $=20.65$ days.

effects of a strong current. Later this current was estimated to be as much as 3-4 knots. Based on the consensus of opinions of the experience onboard ship, the drill ship had drilled successfully in similar sea conditions. It was agreed, however, that this may have been the strongest current ever experienced during any of the Challenger's drilling operations.

The pipe failure, as best can be determined at this time, occurred in a new joint of 5" O.D. drill pipe. There was some degree of internal corrosion and pitting evidenced in the failed joint. Pictures were taken of the failure for additional study. One may better determine the condition of the pipe by additional inspection of the recovered half of the parted joint, that is by a complete Tuboscope inspection, etc. It is believed that the failure occurred due to the additional stress set up by the vessel movement, pitch and roll, plus the current that was existing at the time of failure. It is believed that the current was setting up stresses in the pipe that were not anticipated due mainly to the fact that the speed of the current was underestimated. There is the possibility that a bottom current in this Drake Passage area could have been affecting the length of the drill string. The corrosion and pitting, as evidenced internally, could have also been a factor in the failure.

On future sites, while experiencing similar conditions, one should endeavor to make every effort to be more mindful of all the forces affecting the drill string. One should not hang the drill string off bottom in any severe seas at all while attempting to position the ship. When experiencing a positioning problem, one should immediately start pulling out of the hole. Once positioning is again satisfactory, the pipe can be run back in the hole. Do not permit the pipe to hang off bottom for any appreciable length of time and allow stresses to concentrate at a point in the drill string; that point being near the bottom of the drill ship.

Due to this drill pipe failure and the excessively long delivery time on 5" O.D. drill pipe, it was deemed necessary by the Deep Sea Drilling Project to set up some operational limits under which to work the drill string in the future. These operational limits are stated as: "The maximum limit under which the drill pipe is to be worked is a vessel roll and/or pitch of $7^{\circ}$. In no case are operations to continue where occasional vessel rolls and/or pitch exceed $9^{\circ}$." During the drilling of the remaining sites of Leg 36, these limits were found to be quite reasonable.

\section{ADDENDUM II}

\section{ANALYSIS OF FACTORS RESULTING IN THE LOSS OF HOLE 328B}

Hole $328 \mathrm{~B}$ had penetrated to 5574 meters at the time operations had to be shut down for an iceberg approaching the ship. All sediments penetrated had been clay-type sediments which are soft but normally offer good hole conditions. Fifty barrels of get mud was pumped in the hole before bit was pulled off bottom. The bit was pulled to 5250 meters to wait out the movement of the iceberg. Sediments at 5250 meters (ocean floor at $5103 \mathrm{~m}$ ) were soft clays. Reference is made to the drilling recorder chart. The bit hung at 5250 meters for approximately $1 \mathrm{hr}$ and $40 \mathrm{~min}$ with the ship's positioning system and the heave of the ship causing bit to move and/or reciprocate about the well bore. One might conclude that this motion caused the bit to sidetrack on the low side of the hole and/or cause a bridge to be formed in the hole at this point. When operations were resumed, it is believed that upon lowering the bit past 5250 meters, the bit started to sidetrack (refer closely to string weight on drilling recorder chart). The driller noticed after running four doubles back in the hole that something did not appear to be proper, that is, he was losing some string weight off the total hook load on the indicator. The pump was kicked on, swivel was in string at the time, and the pipe was reciprocated and pumped for approximately $20 \mathrm{~min}$. The string weight returned to normal. It is now believed that the pump jetted out soft clay ahead of the bit and actually made hole while regaining the string weight. The pipe may or may not have already been bent at this time. At this point (refer to chart), the pipe was continued to be run in the hole in doubles, but a close look at the recorder chart indicates that string weight was started to be lost on first double run in the hole without pump on until approximately 30,000 to $50,000 \mathrm{lb}$ were lost from the total hook load and then as the remaining doubles were run back to bottom, very little if any weight could be detected as being lost from the total string weight. However, now one can be almost certain that the last 10 doubles run were laid on the ocean floor. It was determined after returning to near bottom, that the string weight lost was approximately 30,000 to $50,000 \mathrm{lb}$ and the string could not be rotated. The pump pressure was determined to be normal, but all other factors indicated the bottom-hole assembly had been broken off. The pipe was started out of the hole upon pulling to 5400 meters (assuming string still all in tack), and the total string weight was immediately regained. Upon regaining the normal total string weight, it became apparent what had actually happened to the bit on the way in the hole. The string continued to be pulled out of the hole. At four stands above the bottom-hole assembly, two joints of drill pipe were found to be badly bent as a result of laying over the drill pipe. One other joint was found bent at 39 joints above the top of the bottom-hole assembly, however, this may or may not have been bent due to laying the drill pipe over.

In an effort to eliminate the recurrence of this problem, it is recommended that the following be considered:

1) The bit be reciprocated frequently the maximum distance possible while handling off waiting during similar circumstances.

2) Proceed back to bottom very cautiously watching the weight indicator closely, being sure the correct string weight is maintained at all times on the indicator.

3) If in doubt at all as to whether the bit is taking weight, pick up swivel and circulate and ream the bit back to bottom while maintaining full string weight on the indicator. This may tend to sidetrack the hole but more important this procedure will prevent damaging and/or losing drill pipe and/or bottom-hole assembly. 